\title{
Aktivitas Membran Bakiko (Bayam-Kitosan-Kolagen) terhadap Ekspresi Matriks Metaloproteinase-9 pada Luka Bakar Derajat II
}

\section{(Activity of Bakiko Membrane (Spinach-Chitosan-Collagen) to Matrix Metalloproteinase-9 Expression on Grade II Burn Wound)}

\author{
Hazmi Dwinanda Nurqistan, Al Munawir, Ika Rahmawati Sutejo \\ Program Studi Pendidikan Dokter, Fakultas Kedokteran Universitas Jember \\ Jalan Kalimantan 37, Jember 68121 \\ e-mail: almunawir.fk@unej.ac.id
}

\begin{abstract}
Matrix metalloproteinase-9 (MMP-9) plays an important role in regulating the degradation and deposition extracellular matrix (ECM) that are important for wound reepithelization. However, excessive protease activity can lead to delayed wound healing. Kaemferol in spinach can inhibit the activity of MMP-9. Chitosan and collagen can help tissue growth and have an antimicrobial effect. Chitosan-collagen membranes have been widely used for wound healing but, the results are unsatisfactory. Therefore, the researcher wanted to know the activity of bakiko (Spinach-Chitosan-Collagen) membrane to MMP-9 expression on second degree burn with immunohistochemical method. This research was trueexperimental laboratories design with post test only control group design. The experimental animals used were 36 white wistar rats (Rattus novergicus) male, divided into 4 groups ie control group, negative control, positive control (bioplacenton), and treatment (bakiko membrane). Data were obtained by calculating MMP-9 using ImageJ software. The analysis using anova test showed that $p$ value less than 0.05 indicated a significant difference. This study showed that there was a decrease in MMP-9 activity by bakiko membrane in grade II burn with immunohistochemical method in wistar rats.
\end{abstract}

Keywords: Spinach, Chitosan, Collagen, Burn wound, Matrix Metalloproteinase-9

\begin{abstract}
Abstrak
Matriks metalloproteinase-9 (MMP-9) memainkan peran penting dalam mengatur degradasi dan deposisi extracellular matrix (ECM) yang penting untuk reepitelisasi luka. Namun, aktivitas protease yang berlebih dapat menyebabkan penyembuhan luka terhambat. Kaemferol dalam bayam dapat mengendalikan aktivitas MMP-9. Kitosan dan kolagen menyerupai komponen ECM sehingga dapat membantu pertumbuhan jaringan dan bersifat sebagai antimikroba. Membran kitosan-kolagen telah banyak dimanfaatkan untuk penyembuhan luka namun, hasilnya kurang memuaskan. Oleh karena itu, peneliti ingin mengetahui aktivitas membran bakiko (bayam-kitosan-kolagen) terhadap ekspresi MMP-9 pada luka bakar derajat II dengan metode imunohistokimia. Penelitian ini dilakukan secara true-experimental laboratories design dengan rancangan post test only control group. Hewan coba yang digunakan adalah tikus putih (Rattus novergicus) galur wistar jantan sebanyak 36 ekor, dibagi menjadi 4 kelompok yakni kelompok kontrol, kontrol negatif, kontrol positif yang diberikan bioplacenton, dan perlakuan yang diberikan membran bakiko. Data diperoleh melalui penghitungan MMP-9 menggunakan software ImageJ pada sediaan imunohistokimia. Analisis dengan menggunakan uji anova didapatkan nilai $p$ kurang dari 0,05 yang menunjukkan adanya perbedaan yang signifikan. Penelitian ini menunjukkan bahwa terjadi penurunan aktivitas MMP-9 oleh membran bakiko pada luka bakar derajat II dengan metode imunohistokimia pada tikus wistar.
\end{abstract}

Kata kunci: bayam, Kitosan, Kolagen, Luka Bakar, Matriks Metaloproteinase-9 


\section{Pendahuluan}

Luka bakar merupakan masalah kesehatan global dengan estimasi perhitungan sebesar 265.000 kematian setiap tahunnya. Lebih dari 500.000 luka bakar luka terjadi setiap tahun di Amerika Serikat. Meskipun sebagian besar luka bakar ini ringan, kira-kira 40.000 sampai 60.000 pasien luka bakar memerlukan pertolongan di rumah sakit untuk perawatan yang tepat [1]. Prevalensi cedera di Indonesia adalah $8,2 \%$ dan $0,7 \%$ dari keseluruhan cedera disebabkan karena terbakar. Penyebab cedera karena terbakar ditemukan proporsi tertinggi di Papua (2\%) dan terendah (tanpa kasus) di Kalimantan Timur [2].

Luka bakar adalah cedera pada kulit dan jaringan sekitarnya akibat suhu, bahan kimia, listrik, atau radiasi. Menurut Clouatre et al. di daerah Ontario, Canada, sebesar 32,7\% luka bakar disebabkan karena api, $27 \%$ karena listrik, dan $19,7 \%$ disebabkan oleh air mendidih [3]. Luka bakar membutuhkan perawatan luka yang kompleks karena merupakan luka terbuka yang merusak epidermis dan jaringan-jaringan di bawahnya. Pada luka bakar dapat terjadi proses inflamasi, infeksi, dan pada keadaan yang parah, penguapan cairan tubuh diikuti dengan hilangnya panas dan energi tubuh [4]. Oleh karena itu pada luka bakar, dibutuhkan obat-obatan yang dapat mempercepat epitelisasi kulit, memiliki sifat antimikroba, mampu memodulasi inflamasi, dan mencegah penguapan cairan melalui kulit.

Matriks metaloproteinase (MMP) dapat ditemukan pada luka bakar. MMP tersebut memainkan peran penting dalam mengatur degradasi dan deposisi extracellular matrix (ECM) yang penting untuk reepitelisasi luka. Salah satu MMP yang paling berperan dalam penyembuhan luka adalah MMP-9. Namun, aktivitas protease yang berlebih dapat menyebabkan penyembuhan luka terhambat. Penyembuhan luka membutuhkan aktivitas MMP yang terkontrol pada semua tahap proses penyembuhan luka [5].

Bayam merupakan tanaman yang kaya vitamin dan mineral. Senyawa efektif dalam bayam termasuk zink, glutamin, arginin, dan antioksidan seperti kaemferol. Glutamin berperan dalam proses penyembuhan luka dan mengurangi inflamasi [6]. Arginin dapat meningkatkan proliferasi fibroblast [7]. Fibroblas merupakan salah satu sel yang mampu memproduksi MMP saat terjadinya luka. Aktivitas MMP yang meningkat dapat menyebabkan penyembuhan luka terhambat. Kaemferol merupakan salah satu antioksidan yang dapat mensupresi aktivitas MMP-9 [8]. Oleh karena itu, adanya kandungan kaemferol dalam bayam diharapkan dapat mengendalikan aktivitas enzimenzim protease dalam proses penyembuhan luka.

Kitosan merupakan polisakarida kationik alami yang berasal dari exoskeleton kerang, kepiting, udang, serangga, jamur, dan ganggang laut memiliki peran dalam penyembuhan luka. Kitosan menyerupai komponen ECM sehingga dapat membantu pertumbuhan jaringan, menginisiasi proliferasi sel fibroblas, dan menstimulasi sintesis kolagen. Kitosan juga bersifat antimikroba terhadap berbagai bakteri, jamur, dan alga [9].

Kolagen merupakan unsur penting ECM yang menguntungkan karena memiliki efek homeostasis, antigenitas rendah, biokompatibilitas yang baik, dan kekuatan mekanik yang tinggi untuk diterapkan dalam soft tissue engineering. Proses morfogenesis, remodeling jaringan, dan perbaikan jaringan memerlukan kolagen untuk memungkinkan pertumbuhan organ dan migrasi sel [9].

Berdasarkan penelitian-penelitian yang telah dilakukan, bayam, kitosan, dan kolagen dapat bermanfaat dalam proses penyembuhan luka. Membran kitosan-kolagen telah banyak dimanfaatkan untuk penyembuhan luka namun, hasilnya kurang memuaskan [10]. Adanya penambahan bayam pada membran kitosankolagen diharapkan dapat menguatkan efek terapinya. Oleh karena itu, peneliti ingin mengetahui aktivitas membran bakiko terhadap ekspresi MMP-9 pada luka bakar derajat II dengan metode imunohistokimia.

\section{Metode Penelitian}

Penelitian ini dilakukan secara trueexperimental laboratories design dengan rancangan post test only control group. Penelitian ini telah mendapat persetujuan etik dari komisi etik Fakultas Kedokteran Universitas Jember dengan nomor 731/H25.1.11/KE/2016 Penelitian dilakukan di Laboratorium Kimia Fakultas Teknologi Hasil Pangan Politeknik Negeri Jember, Laboratorium Fisiologi, Laboratorium Histologi Fakultas Kedokteran Gigi Universitas Jember, Laboratorium Biokimia, dan Laboratorium Patologi Anatomi Fakultas Kedokteran Universitas Jember. Hewan coba yang digunakan adalah tikus putih (Rattus novergicus) galur wistar jantan berumur 2-3 bulan 
dengan berat badan 150-200 gram yang sehat dan memiliki kulit yang normal sebanyak 36 ekor, dibagi menjadi 4 kelompok yakni kelompok kontrol, kontrol negatif, kontrol positif yang diberikan bioplacenton, dan perlakuan yang diberikan membran bakiko. Kelompok dibagi menjadi tiga sub kelompok berdasarkan lama pemberian membran bakiko dan hari pengamatan yakni hari ke-3, 7, dan 21 setelah pemberian luka bakar. Suhu ruangan pemeliharaan sebesar $27{ }^{\circ} \mathrm{C}\left( \pm 3^{\circ} \mathrm{C}\right)$. Tikus diberi pakan standar dan diberikan air minum secara ad libitum.

Bayam segar diekstraksi menggunakan blender dengan pelarut aquades perbandingan $1: 1$. Kemudian disaring menggunakan saringan tahu dan diambil hasil ekstraksinya. Selanjutnya dilakukan pengeringan dengan metode freeze drying untuk mendapatkan ekstrak bayam kering.

Larutan kolagen dengan konsentrasi 0,41 $\mathrm{mg} / \mathrm{mL}$ dicampur dengan kitosan dalam $0,5 \mathrm{M}$ asam asetat 1:1. Setelah itu, ditambahkan ekstrak bayam. Membran dicetak dengan menuangkan komposit kolagen-kitosan ke dalam plat kaca yang didalamnya telah terdapat kasa steril dengan ukuran $2,5 \mathrm{~cm} \times 2,5 \mathrm{~cm}$ dan meratakan permukaannya dengan ketebalan \pm 1 $\mathrm{mm}$. Kemudian kita diamkan selama 24 jam pada suhu $4{ }^{\circ} \mathrm{C}$.

Hewan coba dibius dengan ketamin 0,1 cc intramuskular. Kulit punggung dicukur dan menyeluruh. Luka bakar dibuat sebagai luka bakar kontak dengan putaran diameter pelat logam $2 \mathrm{~cm}\left(105^{\circ} \mathrm{C}, 5\right.$ detik) pada sisi kanan dan kiri punggung tikus. Setelah tikus di induksi luka bakar, tikus diperlakukan sesuai kelompok perlakuannya. Kelompok $\mathrm{K}(+)$ diberi bioplacenton 1 jam setelah induksi dan kelompok $P$ diberikan membran bakiko pada waktu yang sama dengan kelompok $\mathrm{K}(+)$. Bioplacenton dioleskan setiap hari dan membran bakiko ditempelkan pada luka bakar diganti setiap 3 hari sekali.

Hewan coba diterminasi pada hari ke-3, 7, dan 21 dengan jumlah tiga ekor tikus per kelompok tiap kali terminasi. Setelah itu, jaringan kulit yang diberi perlakuan kemudian diambil dan dibuat sediaan imunohistokimia. Jaringan kulit yang telah diambil kemudian disimpan dalam formalin 10\%. Pewarnaan menggunakan kit imunohistokimia (Scytech Laboratories). MMP-9 dilihat dengan bantuan mikroskop perbesaran 400 kali. Pengamatan dilakukan oleh tiga orang pengamat dengan metode blinding pada enam lapang pandang dengan bantuan graticulae. Hasil dari perhitungan ini kemudian dirata-rata.
Dari hasil pengamatan yang diperoleh, data ratarata jumlah MMP-9 per lapang pandang dianalisis secara statistik dengan menggunakan ShapiroWilk untuk menguji normalitas data dan dilanjutkan dengan analisis statistik One Way Anova.

\section{Hasil}

Gambaran imunohistokimia kulit tikus dari perlakuan yang diberikan dapat dilihat pada gambar 1; 2; dan 3. Setelah dilakukan penghitungan dengan software ImageJ dan dirata-rata, nilai rata-rata MMP-9 setiap kelompok dapat dilihat pada tabel 1 .
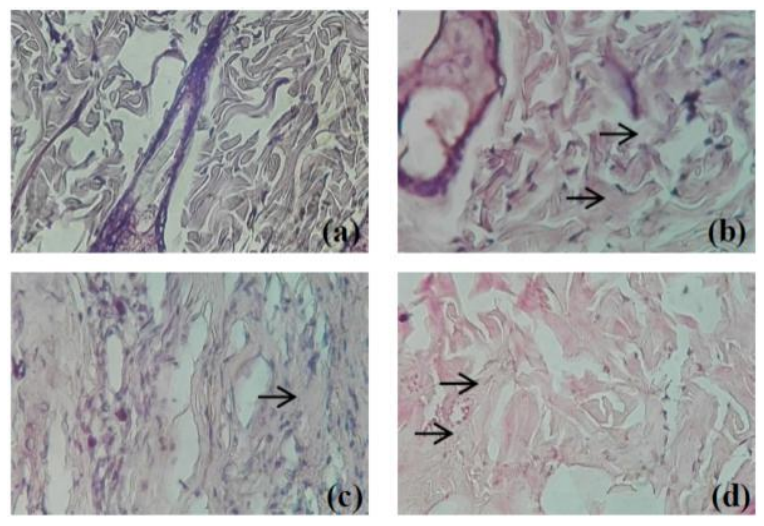

Gambar 1. Pengamatan imunohistokimia kulit tikus hari ke-3 menggunakan mikroskop dengan perbesaran 400x, kontrol (a), kontrol negatif (b), bioplacenton (c), dan membran bakiko (d). Warna coklat dalam gambar menunjukkan ekspresi MMP-9 (panah hitam)
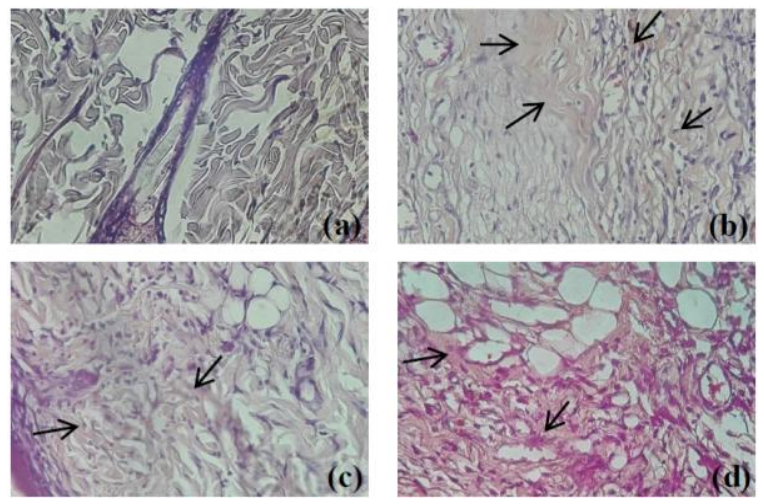

Gambar 2. Pengamatan imunohistokimia kulit tikus hari ke-7 menggunakan 
Nurqistan, et al., Aktivitas Membran Bakiko (Bayam-Kitosan-Kolagen) terhadap Ekspresi ....

mikroskop dengan perbesaran 400x, kontrol (a), kontrol negatif (b), bioplacenton (c), dan membran bakiko (d) Warna coklat dalam gambar menunjukkan ekspresi MMP-9 (panah hitam)
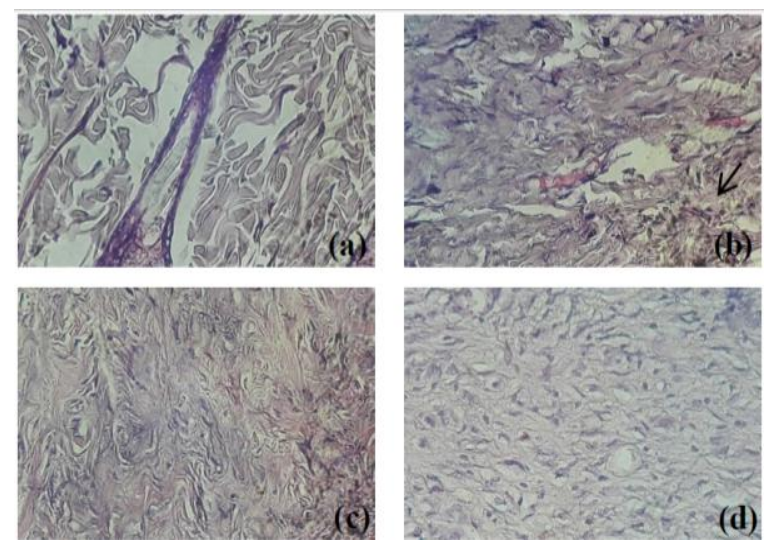

Gambar 3. Pengamatan imunohistokimia kulit tikus hari ke-21 menggunakan mikroskop dengan perbesaran 400x, kontrol (a), kontrol negatif (b), bioplacenton (c), dan membran bakiko (d) Warna coklat dalam gambar menunjukkan ekspresi MMP-9 (panah hitam)

Hasil uji normalitas menunjukkan data terdistribusi normal $(p>0,05)$ dan homogen. Data tersebut selanjutnya dianalisis dengan menggunakan uji One Way Anova dan didapatkan nilai $p$ kurang dari 0,05 yang menunjukkan adanya perbedaan yang signifikan.

Tabel 1. Nilai Rata-rata Ekspresi MMP-9

\begin{tabular}{|c|c|c|c|c|}
\hline $\begin{array}{l}\text { Hari } \\
\text { Pen } \\
\text { gam } \\
\text { atan }\end{array}$ & $\begin{array}{c}\text { Kontrol } \\
\text { (pixel) }\end{array}$ & $\begin{array}{l}\text { Kontrol } \\
\text { Negatif } \\
\text { (pixel) }\end{array}$ & $\begin{array}{l}\text { Bioplacent } \\
\text { on (pixel) }\end{array}$ & $\begin{array}{c}\text { Membran } \\
\text { Bakiko } \\
\text { (pixel) }\end{array}$ \\
\hline 3 & $\begin{array}{c}130972,75 \\
\pm \\
70387,12\end{array}$ & $\begin{array}{c}362417,50 \\
\pm \\
306703,9\end{array}$ & $\begin{array}{c}243015,25 \\
\pm \\
225247,1\end{array}$ & $\begin{array}{c}697051,50 \\
\pm \\
196543,7\end{array}$ \\
\hline 7 & $\begin{array}{c}130972,75 \\
\pm \\
70387,12\end{array}$ & $\begin{array}{c}739531,75 \\
\pm 169087\end{array}$ & $\begin{array}{c}202665,25 \\
\pm \\
96347,13\end{array}$ & $\begin{array}{c}597887,50 \\
\pm \\
152655,1\end{array}$ \\
\hline
\end{tabular}


bayam menghambat MMP-9, serta adanya kolagen dalam membran bakiko dapat menjelaskan terjadinya percepatan fase inflamasi [13].

Pada pengamatan hari ke-7, terjadi penurunan ekspresi MMP-9 pada kelompok bioplacenton dan membran bakiko. Penurunan tersebut menandakan bahwa fase inflamasi telah berakhir yang sekaligus merupakan tanda awal dari fase proliferasi [11]. Hasil tersebut berbeda dengan kelompok kontrol negatif yang ekspresi MMP-9nya mencapai puncak pada hari ke-7. Terjadinya perlambatan fase inflamasi pada kelompok kontrol negatif tersebut menyebabkan keterlambatan penyembuhan luka.

Pada hari ke-21, semua kelompok yang diberikan luka bakar mengalami penurunan ekspresi MMP-9. Penurunan ekspresi MMP-9 kelompok bioplacenton dan membran bakiko kurang dari kelompok kontrol yang menandakan bahwa adanya aktivitas inhibisi MMP-9. Pada hari ke-21 seluruh luka pada tikus kelompok bioplacenton dan membran bakiko pada penelitian ini telah sembuh sempurna. Beberapa tikus pada kelompok membran bakiko sembuh sebelum hari ke-21. Fibroblas pada fase proliferasi memperbanyak diri dan menghasilkan proteinase seperti MMP-9 untuk mendegradasi ECM. Komponen kolagen dan ECM lainnya membentuk jaringan granulasi yang mengisi celah luka dan menyediakan sarana untuk adhesi sel, migrasi, pertumbuhan dan diferensiasi selama perbaikan luka [14]. Hal tersebut menjelaskan peran membran bakiko yang mengandung kaemferol, kolagen, dan kitosan.

Ekstrak bayam sebagai penyembuh luka telah banyak digunakan oleh beberapa peneliti lainnya. Umumnya ekstrak bayam digunakan sebagai obat oral dan belum ada yang mengkombinasikannya dengan kitosan-kolagen. Bayam mengandung glutamin, kaemferol, dan arginin. Glutamin berperan penting dalam penyembuhan luka dengan meningkatkan sintesis kolagen. Beberapa penelitian menunjukkan suplementasi arginin dapat meningkatkan penyembuhan luka [6]. Selain itu, arginin dapat meningkatkan proliferasi fibroblas [7]. Sedangkan kaemferol merupakan salah satu antioksidan yang dapat mensupresi aktivitas MMP-9 [8]. Membran kitosan-kolagen dapat mensupresi ekspresi MMP-9 [15]. Turunnya ekspresi MMP-9 dapat mempercepat penyembuhan luka.

Suplementasi bayam pada tikus diabetes yang diberikan luka akut memberikan hasil yang cukup memuaskan. Tikus diabetes dengan luka akut yang diberikan suplemen bayam sembuh pada hari yang sama seperti tikus non diabetes dengan luka akut yaitu hari ke-21 [6]. Menggunakan bayam sebagai obat topikal akan mampu mempercepat penyembuhan luka daripada menggunakannya secara oral [16].

Kolagen merupakan konstituen mayor dari ECM. Kolagen dapat berperan dalam peningkatan migrasi makrofag ke bagian yang mengalami luka dan dapat mengurangi inflamasi berkepanjangan. Signaling antara endothelial cell-surface receptors dan kolagen menstimulasi migrasi dan stimulasi sel endotel, sehingga gangguan vaskularisasi pada luka dapat diatasi $[17,18]$.

Kitosan dan derivatnya telah lama digunakan sebagai obat topikal untuk perawatan luka karena memiliki peran hemostatik, antimikroba, dan mampu menstimulasi penyembuhan luka. Kitosan merupakan material yang bersifat nontoksik, biokompatibel, dan biodegradabel [19]. Pada penelitian Ramasamy dan Shanmugam, kelompok tikus yang diberi luka berdiameter $20 \mathrm{~mm}$ lalu diterapi dengan membran kitosan-kolagen mengalami pengurangan luas luka $96,25 \%$ pada hari ke-7 sedangkan kelompok kontrol hanya 33,75\% [20]. Oleh karena itu, penggabungan antara bayam, kitosan dan kolagen sebagai membran penyembuh luka pada luka bakar merupakan hal yang menguntungkan.

\section{Simpulan dan Saran}

Berdasarkan hasil penelitian dapat disimpulkan bahwa terjadi penurunan aktivitas MMP-9 oleh membran bakiko pada luka bakar derajat II dengan metode imunohistokimia secara in vivo dengan perbedaan bermakna pada hari ke-3, 7, dan $21(p<0,05)$.

Saran dari hasil penelitian yang diperoleh, perlu dilakukan penelitian lebih lanjut tentang dosis efektif membran bakiko pada proses penyembuhan luka bakar dengan sampel yang lebih besar. Selain itu, perlu dilakukan uji ekspresi MMP-9 menggunakan metode selain imunohistokimia dan pengujian efek samping dan efek toksik membran bakiko pada proses penyembuhan luka bakar.

\section{Ucapan Terima Kasih}

Ucapan terima kasih kepada Kementerian Riset, Teknologi, dan Pendidikan Tinggi Republik Indonesia dalam Program Kreativitas Mahasiswa dan Fakultas Kedokteran Universitas Jember 
yang telah memberikan dukungan dalam pendanaan penelitian.

\section{Daftar Pustaka}

[1] Townsend CM, Beauchamp RD, Evers BM, Mattox KL. Sabiston Textbook of Surgery: The Biological Basis of Modern Surgical Practice. 19th ed. Elsevier Saunders, 2012.

[2] Trihono. Riset Kesehatan Dasar 2013. Badan Penelitian Dan Pengembangan Kesehatan Kementerian Kesehatan RI, 2013.

[3] Clouatre E, Gomez M, Banfield J, Jeschke MG. Work-related Burn Injuries in Ontario, Canada: a Follow Up 10-year Retrospective Study. Burns. Journal of the International Society for Burn Injuries. 2013 Jan; 39(6):1091-1095.

[4] Rowan MP, Cancio LC, Elster EA, Burmeister DM, Rose LF, Natesan S, et al. Burn Wound Healing and Treatment: Review and Advancements. Critical Care. 2015 Jun; 19:243.

[5] Caley MP, Martins VLC, O'Toole EA. Metalloproteinases and Wound Healing. Advances in Wound Care. 2015 Apr; 4(4): 225-234.

[6] Rahati S, Eshraghian MR, Ebrahimi A, Pisva $\mathrm{H}$. Effect of Spinach Aqueous Extract on Wound Healing in Experimental Model Diabetic Rats with Streptozotocin. J Sci Food Agri. 2016 May; 96: 2337-2343.

[7] Fujiwara TS, Ichibori KR, Tanigawa T, Magome T, Shingaki K, Miyata S, et al. LArginine Stimulates Fibroblast Proliferation through the GPRC6A-ERK1/2 and PI3K/Akt Pathway. Plos One. 2014 Mar; 9(3).

[8] Choi YJ, Lee YH, Lee ST. Galangin and Kaempferol Suppress Phorbol-12-Myristate13-Acetate-Induced Matrix Metalloproteinase-9 Expression in Human Fibrosarcoma HT-1080 Cells. Mol Cells. 2015 Des; 38(2):151-155.

[9] Mc Bane JE, Vulesevic B, Padavan DT, Mc Ewan KA, Korbutt GS. Evaluation of a Collagen-Chitosan Hydrogel for Potential Use as a Pro-Angiogenic Site for Islet Transplantation. Plos One. 2013 Okt; 8(10): e77538.
[10] Wang W, Lin S, Xiao Y, Huang Y, Tan Y, Cai $\mathrm{L}$, Li X. Acceleration of Diabetic Wound Healing with Chitosan-crosslinked Collagen Sponge Containing Recombinant Human Acidic Fibroblast Growth Factor in Healingimpaired STZ Diabetic Rats. Elsevier. 2008 Jan; 82: 190-204.

[11] Wall SJ, Bevan D, Thomas DW, Harding KG, Edwards DR, Murphy G. Differential Expression of Matrix Metalloproteinases During Impaired Wound Healing of the Diabetes Mouse. The Journal Of Investigative Dermatology. 2002 July; 91-98.

[12] Dasu MR, Spies M, Barrow RE, Herndon DN. Matrix Metalloproteinases and Their Tissue Inhibitors in Severely Burned Children. Wound Repair Regen. 2003 May; 11:177-180.

[13] Rosique RG, Rosique MJ, Junior JAF. Curbing Inflammation in Skin Wound Healing: A Review. International Journal of Inflammation. $2015 \mathrm{Jul} ;$ 1-9.

[14] Landen NX, Li D, Stahle M. Transition from Inflammation to Proliferation: a Critical Step During Wound Healing. Cell. Mol. Life Sci. 2016 Okt; 73:3861-3885.

[15] Kirichenko AK, Bolshakov IN, Ali-Riza AE, Vlasov AA. Morphological Study of Burn Wound Healing with the Use of CollagenChitosan Wound Dressing. Bulletin of Experimental Biology and Medicine. 2013 Mar; 154(11): 652-656.

[16] Lipsky BA, Hoey C. Topical Antimicrobial Therapy for Treating Chronic Wounds. Clinical Infectious Diseases. 2009 Nov; 49:1541-9.

[17] Elgharably H, Roy S, Khanna S, Abas M, Ghatak PD, Das A, et al. A Modified Collagen Gel Enhances Healing Outcome in a Pre- Clinical Swine Model of Excisional Wounds. Wound Repair Regen. 2013 Apr; 21(3): 473-481.

[18] Elgharably H, Ganesh K, Dickerson J, Khanna S, Abas M, Ghatak PD, et al. A Modified Collagen Gel Dressing Promotes Angiogenesis in a Pre-Clinical Swine Model of Chronic Ischemic Wounds. Wound Repair Regen. 2014 Jan; 22(6): 720-729.

[19] Tianhong D, Masamitsu T, Ying-Ying $H$, 
Nurqistan, et al., Aktivitas Membran Bakiko (Bayam-Kitosan-Kolagen) terhadap Ekspresi ....

Hamblin MR. Chitosan Preparations for Wounds and Burns: Antimicrobial and Wound Healing effects. Expert Rev Anti Infect Ther. 2011 Jul; 9(7): 857-879.

[20] Ramasamy P, Shanmugam
Characterization and Wound Healing Property of Collagen-chitosan Film from Sepia kobiensis. International Journal of Biological Macromolecules. 2014 Des; 74:93-102. 